\title{
As Ideias que Fazem 0 Estado Andar: Imaginação Espacial, Pensamento Brasileiro e Território no Brasil Central*
}

\section{João Marcelo Ehlert Maia}

Professor adjunto do Centro de Pesquisa e Documentação de História Contemporânea do Brasil (CPDOC), da Fundação Getulio Vargas (FGV). E-mail: João.maia@fgv.br

$\mathrm{O}$ chamado pensamento social brasileiro constitui uma das mais longevas áreas de pesquisa nas nossas ciências humanas, como atestam a duração e a regularidade do grupo de trabalho dedicado ao tema na Associação Nacional de Pós-Graduação e Pesquisa em Ciências Sociais (Anpocs) (Oliveira, 1999). Embora seja um campo marcado por um decidido enfoque histórico, não são poucos os intérpretes contemporâneos que veem na imaginação ilustrada praticada no Brasil chaves analíticas para o desvendamento de temas e problemas atuais (Vianna, 1997; Brandão, 2005). Recentemente, pesquisadores da área têm mostrado grande interesse em investigar o efeito social produzido pelas obras e ideias clássicas do ensaísmo nacional, como forma de entender a relação entre pensamento brasileiro e nation-building (Botelho, 2007). Essa relação permaneceu por muito tempo como óbvia, mas pouco tratada de forma empírica, sendo analisada apenas sob o prisma das "influências" ou das "afinidades eletivas" entre ideias e modelagem estatal. Este artigo toma um caso específico para discutir essa questão teórica mais ampla, que se relaciona com problemas contemporâneos nas áreas de história intelectual e sociologia da cultura.

\footnotetext{
* Este artigo é resultado da pesquisa "Os tenentes do Oeste: João Alberto, a Fundação Brasil Central e a imaginação espacial brasileira", financiada pelo Conselho Nacional de Desenvolvimento Científico e Tecnológico (CNPq) por intermédio do Edital Universal 2007. A pesquisa contou com o auxílio do bolsista de iniciação científica da Fundação de Amparo à Pesquisa do Estado do Rio de Janeiro (Faperj) Rômulo da Silva Gama.
}

DADOS - Revista de Ciências Sociais, Rio de Janeiro, vol. 53, no3, 2010, pp. 621 a 655. 
O caso analisado será o da Fundação Brasil Central (FBC), órgão especial criado pelo decreto 5.878 de quatro de outubro de 1943 e inicialmente comandado pelo ex-interventor de São Paulo e então diretor da Coordenação de Mobilização Econômica, João Alberto Lins de Barros (1897-1955). A FBC tinha entre seus objetivos declarados "desbravar e colonizar as zonas compreendidas nos altos rios Araguaia, Xingu e no Brasil Central e Ocidental" (Meireles, 1960:274). Esta região era tida como alvo preferencial da chamada "Marcha para Oeste", programa de colonização e ocupação de fronteiras impulsionado por Vargas nos primeiros anos do Estado Novo (Dayrell, 1975).

No desenrolar de suas primeiras atividades, os funcionários e demais participantes da empreitada empregavam um repertório de imagens, categorias e conceitos que se referiam aos espaços interiores do país, mobilizando narrativas, personagens e objetos já cristalizados em obras típicas do que chamamos hoje de pensamento social brasileiro. Usualmente, os intérpretes da Marcha tratam esse trabalho simbólico como exemplo da retórica estatal que engendrava uma ideologia justificadora do projeto de capitalismo autoritário do Estado Novo (Velho, 1976; Esterci, 1977). Sem necessariamente discordar desse aspecto, procuro neste artigo sustentar a hipótese de que as imagens e as narrativas clássicas sobre o Brasil Central constituíam um repertório cultural que era mobilizado pelos agentes envolvidos no projeto da FBC e produzia o próprio objeto sobre o qual a Fundação atuava. Dito de outra forma: não se tratava apenas de estratégias ideológicas de justificação, mas de linguagens específicas que conferiam existência e concretude ao que se acreditava ser o Brasil Central. Essa hipótese exige que se esclareça o que se entende por "pensamento social brasileiro" e "Estado", procedimento fundamental para equacionar a articulação entre ideias e práticas.

O artigo tem quatro seções. Na primeira, apresento uma discussão teórica a respeito dos efeitos das ideias na vida social. O objetivo dessa discussão é sugerir que o pensamento social brasileiro pode ser interpretado como um repertório cultural disponível na forma de linguagens específicas. Em seguida, como o foco do artigo é uma agência do Estado, indico brevemente o caminho metodológico que me pareceu o mais adequado para discutir as práticas estatais. Longe de operar apenas como burocrática resenha bibliográfica, essa seção serve para destrinchar o vocabulário que será empregado na seção seguinte, em que apresento uma breve história da FBC, destacando sua constituição, 
seus esquemas cognitivos e os principais objetos de sua atuação. Após essa seção, apresento um quadro geral do repertório literário e ensaístico que constituiu o universo cultural referente ao Brasil Central e ao Oeste brasileiro. O objetivo é mostrar como o chamado pensamento social brasileiro instituía modos de cognição do Brasil Central. A hipótese subjacente a essa seção é a de que essa geografia não estava dada, mas era recortada pelo trabalho simbólico que fornecia pressupostos cognitivos, traçava fronteiras e delineava os personagens, os objetos e as qualidades desse universo. Finalmente, analiso um conjunto de documentos primários que traduzem adequadamente os contornos do mundo social vislumbrado pela Fundação, tais como relatórios, ofícios e projetos de atuação governamental. O objetivo é produzir evidências do poder configurador do pensamento brasileiro, enfatizando como o trabalho simbólico analisado na terceira seção era mobilizado pelos agentes estatais e fazia o Estado andar. Concluo com algumas sugestões sobre o quanto esse caso pode iluminar aspectos mais gerais das práticas estatais no Brasil.

\section{AS IDEIAS E AS PRÁTICAS ESTATAIS}

Qual o estatuto analítico das ideias como variáveis sociológicas? Este tema, que remonta aos clássicos fundadores da Sociologia, vem ganhando espaço na reflexão de teóricos contemporâneos. Sem pretender esgotar o tema, limito-me aqui a elencar algumas respostas que me parecem extremamente profícuas para a análise proposta. Parto das reflexões da Sociologia Cultural norte-americana contemporânea, que destaca a dimensão performativa e pragmática da cultura e das ideias e de seus efeitos na ação social, o que irá me permitir conceituar o pensamento social brasileiro como um repertório cultural. Argumento também que uma perspectiva similar pode ser localizada em discussões recentes da Ciência Política voltadas para o papel das ideias como variáveis explicativas. Finalmente, sustento que essa perspectiva deve estar articulada a uma reflexão sobre as práticas por intermédio das quais esse repertório é mobilizado. Para tanto, valho-me de leituras sociológicas e antropológicas sobre o Estado, extraindo delas procedimentos metodológicos que permitem equacionar os temas da pesquisa.

No âmbito da Sociologia, Ann Swidler produziu interessante saída para o entendimento de como a cultura afeta ações sociais. Em seu livro sobre a experiência do amor tal como vivenciado no mundo con- 
temporâneo (Swidler, 2003), ela argumenta que as ideias, as categorias e as crenças associadas ao tema, e contidas em livros, filmes e contos, devem ser tratadas como parte integrante de um tool kit (caixa de ferramentas). Esse kit seria usado pelos agentes a partir de diferentes estratégias elaboradas diante de necessidades situacionais específicas. Ou seja, a cultura não se efetivaria como um todo orgânico e coerente, espécie de estrutura que é internalizada pelos sujeitos, mas como um conjunto de pistas e modos de enunciação utilizados tanto de forma comprometida, quanto cínica ou mesmo desinteressada. $\mathrm{O}$ alvo de Swindler é a releitura de Weber produzida pela Sociologia Parsoniana, que trataria a cultura como um conjunto de normas e valores internalizados.

A perspectiva avançada por Swidler encontra eco no trabalho do sociólogo Paul DiMaggio (1997) sobre cultura e cognição. Ao buscar nas pesquisas realizadas no campo da Psicologia pistas e indicações sobre os modos práticos pelos quais os sujeitos operam com regras culturais, DiMaggio encontra suficiente empiria para defender a tese de que a cultura é um conjunto de orientações e enunciados que são acionados de maneira reflexiva e situada por parte dos atores sociais. Ou seja, nossos usos da cultura são eminentemente fragmentários e não necessariamente coerentes.

O que essas análises podem nos dizer sobre o problema teórico analisado neste artigo? Ora, as contribuições de Swindler e DiMaggio mostram que o efeito das ideias - tomadas aqui como elementos do universo cultural mais amplo de que falam os autores - é produzido a partir de situações específicas e nem sempre preserva uma dimensão orgânica e coerente que normalmente associamos à palavra cultura. Trata-se, portanto, de reconhecer a dimensão criativa e contingente dos modos pelos quais os atores sociais lidam com o repertório de objetos culturais. No caso do objeto deste artigo, evita-se assim uma visão por demais organicista da relação entre cultura e Estado, como se este refletisse algum Zeitgeist de forma homogênea.

Perspectiva aparentada pode ser encontrada em algumas contribuições recentes da Ciência Política dedicadas ao estudo das ideias como variáveis explicativas. Em artigo sobre o tema, Jennifer Hochschild (2006) argumenta que ideias contribuem para modelar cognitivamente o ambiente percebido pelos atores institucionais, rotinizando-se na prática desses atores e permitindo o enquadramento de problemas e 
temas tidos como públicos. Essa abordagem das ideias como exercendo um efeito causal não mecânico, mas constitutivo e pragmático, encontra-se disseminada nesse tipo de literatura, como atesta o balanço recente efetuado por Gofas e Hay (2008). Conforme enfatizam esses autores, o aspecto relevante dessas reflexões é a crítica ao dualismo ontológico entre ideias e interesses e a ênfase na não linearidade causal, isto é, ideias não agem como variáveis independentes fixas e estáveis, mas são ativadas de forma contingente em função de dinâmicas histórico-institucionais específicas. Assim, não faz sentido analisar o efeito das ideias sob o prisma de uma teoria tradicional da causalidade, que exigiria a observação da regularidade de efeitos no tempo.

Contudo, creio que algumas dessas perspectivas com tinturas pragmatistas descuram dos constrangimentos estruturais que modelam a articulação entre ideias e práticas. Em algumas passagens, a visão de Swidler e DiMaggio, por exemplo, aproxima-se de uma teoria da escolha racional, postulando um uso por demais instrumental e reflexivo das ideias por parte de atores supostamente livres e pontuais. Embora esses autores estejam corretos em sustentar que a cultura é antes um repertório fragmentado e disperso do que um todo coerente, falta a eles uma percepção mais adequada dos constrangimentos objetivos que regulam a disseminação cultural e os próprios usos das ideias. Ademais, o foco nas racionalizações discursivas dos agentes não dá conta do modo como o repertório cultural pode formar esses próprios agentes.

No caso analisado neste artigo, estamos tratando de agentes inscritos em redes estatais, que realizavam atividades burocráticas e administrativas num contexto de forte centralização política. Torna-se imperioso entender esse contexto específico como um constrangimento social particular, e creio que a forma mais adequada de fazê-lo é atentar para processos específicos de estatização. Isto é, ao invés de resolvermos o problema simplesmente postulando a existência de um Estado "Leviatã", coeso e compacto, que distribui ordens e sentidos de forma linear, trata-se de analisar as práticas estatais tais como operadas por agentes enredados em redes sociais. Essa perspectiva implica analisar as práticas e os processos, e não a substância específica de um ator hipostasiado.

Nas últimas décadas, numerosas abordagens teóricas sobre o tema do Estado passaram a adotar uma perspectiva mais descentrada sobre esse objeto. A despeito das divergências inevitáveis contidas nesses registros, pode-se dizer que houve uma relativa convergência quanto à 
necessidade de desagregar o Estado e tomar como objeto analítico os mecanismos e as práticas que constituem formas de autoridade estatal em contextos concretos.

Em artigo sobre o debate em torno do Estado na Ciência Política norte-americana, Mitchell (1991) argumentou que a literatura do final dos anos 1970 que voltou a tratar o Estado como um ator político autônomo - em especial o grupo de Peter Evans e Theda Scokpol - falhou ao não explicar os mecanismos que produzem as fronteiras entre este ator e a sociedade civil, naturalizando uma diferença que seria, antes de tudo, resultado histórico e plural de práticas sociais. Mobilizando um instrumental foucaultiano, Mitchell sustenta que essa distinção não é dada, mas produzida por intermédio de práticas disciplinares de vigilância, controle e regulação espacial. Esse conjunto disperso de práticas produziria o Estado como o resultado de uma diferença.

Para além da matriz teórica que informa Mitchell, importa aqui reter a conclusão do autor a respeito da necessidade de se enfocar o Estado por intermédio de práticas, e não tomá-lo como uma entidade subjetiva dotada de intenções e programas coesos. Essa perspectiva pode ser associada a outras contribuições teóricas, estas mais centradas em uma história de longa duração das práticas estatais, como aquelas de Elias (1993) e Tilly (1996). Nessas investigações, o tema da formação é problematizado, o que joga luz para as dinâmicas históricas específicas que permitem explicar o surgimento de formas mais amplas e centralizadas de autoridade. Trata-se, portanto, de buscar uma visão processual do Estado como objeto.

Outra visão processual pode ser rastreada na clássica obra organizada em 1994 por Joseph e Nugent (2006) sobre as formas cotidianas de negociação da autoridade no contexto da Revolução Mexicana. Inspirados pelos debates marxistas ingleses sobre hegemonia e economia moral, bem como pelos trabalhos de sociologia agrária de James Scott, diversos autores trabalham a ideia de formação do Estado para dar conta dos processos mediante os quais a dominação e a hegemonia são constituídas rotineiramente. Isto implica não tomar o Estado nem como um a priori que dispensa explicações, nem como uma máquina coesa que simplesmente impõe regras no modelo top-down. Ao enfatizar a necessidade de se destrincharem os recursos simbólicos e práticos que são operados nesse processo de longa duração, os organizadores afirmam: 
As Ideias que Fazem o Estado Andar: Imaginação Espacial, Pensamento Brasileiro...

Nossa insistência comum em ver hegemonia, cultura, consciência e experiência em movimento na história é em boa medida motivada pela conceituação, intimamente associada, das formações estatais como fundamentalmente processos culturais que têm consequências manifestas no mundo material (Joseph e Nugent, 2006:13, tradução minha).

Como se percebe, o programa desse grupo implica uma forte atenção às dimensões simbólicas e culturais do processo de construção da ordem estatal, aproximando-se, portanto, dos pressupostos teóricos que guiam este artigo. Essa virada "cultural" é mais explícita na coletânea organizada por Steinmetz (1999), em que numerosos autores buscam aquilatar o peso da cultura nos processos de state-formation. A despeito da variedade de abordagens, que oscilam entre análises internalistas de discursos e investigações mais empíricas de processos históricos, é possível sustentar que quase todos os autores evitam tratar a cultura como uma essência coesa e a histórica, espécie de resíduo misterioso que sobra após a análise política "séria", focada em interesses. Não à toa, torna-se fundamental o recurso à Antropologia, que já há algum tempo vem se voltando para o estudo do Estado.

No campo antropológico, autores como John e Jean Commarof (Commarof e Commarof, 1992) argumentaram a respeito da necessidade de uma etnografia das práticas de colonização, evidenciando o quanto o Estado deve ser entendido a partir dos processos empíricos de imposição e negociação da autoridade. Nesse registro, o pesquisador volta-se para casos particulares em que agentes estatais e os sujeitos objetos de sua autoridade produzem contextos de significação em torno do Estado. No Brasil, trabalhos reunidos por Souza Lima (2002) dialogam com a Sociologia Histórica de Tilly e Elias e com essas etnografias estatais para sustentar que a autoridade pública é produzida de forma prática em contextos de estatização, e não pressuposta a partir da delimitação do Estado como uma subjetividade coesa.

Estudos inspirados por preocupações similares caminharam para estratégias de etnografia institucional (Escobar, 1995) e etnografias do Estado (Hansen e Stepputat, 2001). Pesquisas orientadas por essas abordagens voltaram-se para as práticas concretas e historicamente situadas por intermédio das quais formas de autoridade fizeram-se rotinizar na vida social. Isto implicava tomar como objeto relatórios, discursos de agências burocráticas e as práticas cognitivas que organizavam diversas linguagens do Estado. Ou seja, trata-se de problematizar 
o Estado como unidade analítica, inventariando criticamente os rituais e os mecanismos que permitiram a construção cotidiana dessa força estatal. Afinal, se por um lado a Ciência Política interessou-se mais pela cultura, por outro a Antropologia passou a tomar o Estado moderno como seu objeto.

O que se pode extrair, portanto, dessa literatura sobre o Estado, e de que forma ela permite equacionar a explicação dos usos do repertório cultural, tema apresentado anteriormente? Em primeiro lugar, as perspectivas processuais jogam luz sobre as práticas estatais específicas, evitando hipostasiar o Estado como um ente coeso dotado de uma subjetividade que pode ser remetida sempre a um centro ind efinido e pressuposto. No caso desta pesquisa específica, isto permite atentar para as atividades de funcionários, burocratas e militares que estavam operando práticas de estatização. A questão do efeito social das ideias pode (e deve) ganhar mais concretude se recortada a partir de situações específicas nas quais um repertório cultural articula-se a um conjunto de práticas estatais. Evita-se, assim, a visão organicista que enquadra as ideias como um bloco de valores e crenças traduzidas por um Estado-sujeito.

Uma segunda inferência relaciona-se à própria embocadura analítica da pesquisa, já que uma análise da articulação entre cultura e práticas implica tomar como objeto os registros práticos da atividade estatal, tais como: relatórios, pareceres, publicações oficiais, cartas de funcionários etc. Embora este material não seja mobilizado com frequência nos estudos sobre o pensamento social brasileiro, acredito que o corpus burocrático oferece excelente oportunidade para desvendar, na prática, as dinâmicas de mobilização do repertório cultural. Segue-se, portanto, às sugestões de Arturo Escobar (Escobar, 1995), para o qual essa documentação produz efeitos reais no mundo ao instituir esquemas e modos de cognição que organizam os objetos e os sujeitos sobre os quais os burocratas atuam.

\section{A FUNDAÇÃO BRASIL CENTRAL}

A Fundação Brasil Central foi uma agência criada enquanto era operada praticamente. Teve origem na Expedição Roncador-Xingu, empreendimento iniciado em 1943 por iniciativa do então ministro da Coordenação de Mobilização Econômica ${ }^{1}$, João Alberto Lins de Barros. A FBC funcionou com este nome até 1967, quando foi extinta e suas ativi- 
As Ideias que Fazem o Estado Andar: Imaginação Espacial, Pensamento Brasileiro...

dades foram incorporadas à Sudeco (Superintendência de Desenvolvimento do Centro-Oeste). Na pesquisa ora em curso, limito-me a acompanhar os primeiros passos dessa empreitada, contidos em especial entre os anos de 1943 e 1947, período que conforma a gestão de João Alberto e ainda guarda forte componente carismático.

Ressalte-se a diversidade de personagens envolvidos nesta empreitada. No comando da Fundação estava João Alberto, homem de confiança de Vargas, ex-tenente e participante da Coluna Miguel Costa-Prestes. Seu trânsito pelos mais variados cargos do Estado Novo evidencia sua capacidade de mobilizar recursos e legitimidade para a atuação da FBC. Além dele, envolveram-se no projeto outros ex-tenentistas, tais como Artur Hehl Neiva (filho do sanitarista Artur Neiva), burocratas típicos do padrão Departamento Administrativo do Serviço Público (DASP), como Paulo de Assis Ribeiro, jovens aventureiros em busca de consagração sertanista - caso dos irmãos Villas-Bôas - e até mesmo comunistas com passagem pelo Exército, como Silo Meireles. Essa diversidade de quadros atesta a proficuidade de analisar as redes estatais e a estrutura de sentimentos que dava sentido a essa configuração sertanista-estatal ${ }^{2}$, o que implicaria não tratar o Estado como um ator coletivo homogêneo.

A portaria 77 de 3/6/1943, que criou a Expedição, mencionava a necessidade de exploração do maciço central do país com vistas à integração com a Amazônia, destacando-se a região compreendida pelas cabeceiras do Xingu. A expedição teve como ponto de partida a cidade de Uberlândia e era constituída inicialmente por um "alto escalão" comandado por 23 homens e chefiado pelo ex-chefe da guarda pessoal de Getúlio, o coronel Flaviano de Matos Vanique. O registro clássico dessa empreitada que evocava - de forma explícita - os antigos bandeirantes foi produzido pelos conhecidos indigenistas Orlando e Cláudio Villas-Bôas (Villas-Bôas e Villas-Bôas, 1994), que participaram da vanguarda ${ }^{3}$ da marcha juntamente com o outro irmão, Leonardo, que posteriormente assumiu a chefia da Expedição.

Além da Expedição, a FBC abrigava numerosas iniciativas administrativas, econômicas e políticas. Usinas de cana (Usina Central-Sul Goiana e Usina Fronteira), estradas de ferro, bases que dariam origem a cidades, entrepostos comercias que abasteciam as bases, um Setor Norte responsável pela ajuda para o plano de produção de borracha e uma transportadora. Algumas dessas iniciativas eram diretamente contro- 
ladas pela FBC, outras, em especial os entrepostos comerciais, eram organizadas como sociedades anônimas de capital misto que deveriam gerar lucro para acionistas. Por vezes, empresários locais ofereciam instalações e negócios para aquisição pública, o que indica o espaço disponível para a especulação privada.

Havia, de fato, grande liberdade de atuação, o que ocasionava eventuais conflitos com poderes locais e regionais. A documentação analisada evidencia constantes negociações que envolviam a cessão de terras estaduais para a FBC, condição primordial para a realização dessas iniciativas. Note-se que essas "negociações" ocorriam no âmbito do Estado Novo, período de intensa centralização político-administrativa.

À medida que a Expedição percorria seu trajeto pelos interiores de Goiás e Mato Grosso e construía estradas, campos de pouso e redes de comunicação, o governo Vargas se preocupava em dar maior estabilidade à empreitada. Assim, o Decreto no 5.801 de 8 de setembro de 1943 declarava a Expedição como de interesse militar, o que evidencia uma das motivações geralmente citada por comentadores para a Marcha para o Oeste: a preocupação geopolítica com a segurança nacional no contexto da Segunda Guerra.

Em março de 1942, o Brasil assinou os Acordos de Washington, que previam a integração da Amazônia ao esforço de guerra por intermédio da intensificação da produção de borracha. O acordo previa a compra de estoques, quotas de produção e a injeção de capital americano para criar condições seguras de coleta (Oliveira, 2001). No âmbito dos Acordos, o governo federal construiu numerosas agências e órgãos responsáveis pela racionalização produtiva da região, evidenciando uma tentativa de modernizar a gestão de terras e pessoas naquele espaço. Assim, é possível associar a Expedição a esse esforço de guerra, embora a preocupação com a integração nacional e com a dinamização das fronteiras econômicas antecedesse os Acordos, traduzindo-se numa lógica de gestão característica do Estado Novo.

Essa perspectiva é endossada por trabalhos historiográficos sobre a dinâmica das fronteiras no Centro-Oeste. Albanez (2003), por exemplo, mostra como o sul de Mato Grosso foi alvo de uma disputa entre o Estado e a companhia Mate Laranjeira, que explorava a produção de mate e regulava o próprio fluxo de pessoas e bens na região. Dutra e Silva (2002), por sua vez, argumenta que desde os anos de 1930 o Estado de Goiás vinha passando por um processo de expansão das frentes pio- 
neiras, que intensificava a própria expansão das fronteiras econômicas. A criação da Colônia Agrícola Nacional de Goiás em 1942 respondia a esse processo que vinha se processando de maneira irregular e não controlada. Assim, o discurso de Vargas feito em dezembro de 1940 e propagado pelo Departamento de Imprensa e Propaganda (DIP) e seus trabalhadores intelectuais como "O Discurso do Rio Amazonas" pode ser entendido como um evento entre outros, e não necessariamente como marco inaugural desse processo.

Segundo Eliane Dayrell (1975), havia muitos interesses associados à Marcha, o que se traduziu num vasto programa de colonização que implicou a ação e a criação de numerosos órgãos e agências, tais como o Instituto Brasileiro de Geografia e Estatística (IBGE) (1934), a Divisão de Terras e Colonização e o Conselho de Imigração e Colonização (ambos de 1938), entre outros. A Expedição e a FBC inscrevem-se no âmbito desse processo de invenção burocrática.

É difícil, portanto, delimitar uma causa singular para a criação da Fundação, que se articulava a uma dinâmica pública maior, cujo sentido residia na expansão interna das malhas estatais e no controle das fronteiras políticas e econômicas. Esse contexto produzia uma espécie de Estado em movimento, que construía sua legitimidade à medida que se dilatava pelo que se acreditava serem os espaços vazios do país. Importante ressaltar que alguns dos principais personagens dessa empreitada vivenciaram experiências prévias associadas a essa ideia que associava o processo de construção nacional a uma descoberta do Brasil, tido como território a ser desbravado. Era o caso dos tenentes, bem como de alguns jornalistas-aventureiros que iriam acompanhar os passos da Expedição Roncador-Xingu. Pode-se dizer que isso contribuiu para gerar o neobandeirantismo que seria a marca das práticas estatais da FBC. Com esse conceito, refiro-me à forma pela qual os atores enredados nas malhas burocráticas da FBC concebiam a produção do Estado naquele contexto histórico por intermédio de modos de imaginação espacial da Nação, recorrendo ao exemplo do bandeirantismo clássico. Essa concepção se valia de uma concepção aventureira da expansão estatal e empregava categorias tais como "desbravamento" e "penetração" para qualificar sua dinâmica de atuação.

As ideias, categorias e discursos que formatavam esse neobandeirantismo recorriam a um vasto repertório cultural pré-existente, que produzia um espaço específico associado ao "Oeste" ou ao "Brasil Central". 
Se múltiplas eram as causas que explicavam esse processo de expansão estatal, também não são poucas as imagens espaciais que permitiram infundir sentido simbólico e prático ao que se convencionou chamar de Marcha para Oeste. Trata-se, portanto, de decodificar o trabalho simbólico que instituiu esse universo e permitiu a própria existência desse processo incessante de invenção burocrática.

\section{O PENSAMENTO SOCIAL BRASILEIRO E O MUNDO DO BRASIL CENTRAL}

Inicialmente, é interessante notar como a própria definição de "Brasil Central" escapa, e muito, à nossa compreensão contemporânea do Centro-Oeste. Como se percebe pelo roteiro traçado pela RoncadorXingu, o centro do país parecia começar em Uberlândia - a "boca do sertão" - e ir até a fronteira da região amazônica central, estendendo-se pelo Oeste dos estados do Mato Grosso e do Paraná. Essa flexibilidade correspondia, por um lado, à própria indefinição sobre a divisão regional brasileira, assunto que ocupava geógrafos, militares e engenheiros de forma intensa desde as décadas de 1910 e 1920.

No início da década de 1940, essa discussão era um dos temas preferidos dos colaboradores da Revista Brasileira de Geografia. Veja-se, por exemplo, o artigo de Guimarães (1941) sobre o tema, no qual esse membro do Conselho Nacional de Geografia lista as diversas propostas que eram discutidas, formuladas por conhecidos nomes do pensamento espacial brasileiro, tais como Everardo Backheuser e Carlos Delgado de Carvalho.

Por outro lado, essa indefinição indicava a própria dimensão imaginativa presente nessa denominação. "Brasil Central" e "Oeste" pareciam corresponder a quaisquer espaços que fossem possíveis alvos de uma ação integradora do Estado brasileiro e que partilhassem certas qualidades específicas. Mas quais os textos que permitiram a construção dessa cartografia? Faz-se necessário, portanto, delinear, mesmo que de forma inicial, o repertório cultural que foi operado pelos agentes estatais e permitiu a produção posterior de personagens, objetos e espaços. Esse repertório será analisado a partir da fixação de textos que disseminavam modos de cognição do espaço brasileiro, evitando-se assim uma discussão por demais etérea de ideias e "grandes temas".

Como se percebe, parto do pressuposto de que a melhor forma de estudar o efeito das ideias é analisando-as nos seus suportes materiais textos escritos. Creio que isso permite avaliar mais adequadamente 
suas dimensões linguísticas e estratégias retóricas. Além disso, busco também não me fixar apenas nos grandes autores, abrindo o escopo da investigação para o universo comunicativo mais amplo, como forma de compreender os diversos significados associados às categorias que informavam o debate sobre o Brasil Central. Sigo, portanto, algumas das sugestões mais interessantes da chamada Escola de Cambridge (Skinner, 1978; Pocock, 1975)

São muitos os registros literários, científicos e ensaísticos que ajudaram a instituir objetos, personagens e fronteiras do Brasil Central, caso tomemos como eixo cronológico a Primeira República e a década de 1930. Também são variados os círculos intelectuais e as formas de veiculação desses registros, produzidos tanto por geógrafos e precursores da geopolítica, quanto por poetas, escritores, jornalistas e viajantes. É difícil traçar fronteiras precisas entre esses registros tomando por base critérios estilísticos estritos. Para efeitos da presente pesquisa, optei por um tratamento analítico que classifique esse material e evite tratar o repertório cultural como um complexo orgânico e coeso, dotado de um suposto sentido homogêneo.

Assim, optei pela seguinte classificação: a) ensaios clássicos sobre o Brasil Central, geralmente reunidos na coleção Brasiliana. Um exemplar bem conhecido dessa produção é o livro de Couto de Magalhães, Viagem ao Araguaya (1957), reeditado posteriormente na coleção; b) relatórios científicos produzidos a partir da viagem de comissões oficiais às regiões centrais, como os referentes à Comissão Cruls ${ }^{4} \mathrm{e}$ às expedições chefiadas por Rondon; c) ensaios de cunho geopolítico, escritos por militares ou professores de geografia. Entre estes, pode-se citar as obras de Everardo Backheuser (1933) e Mário Travassos (1935); d) romances ou poemas que trabalhavam com imagens geográficas de forma intensa, em geral produzidos sob inspiração modernista. Um exemplo é Plínio Salgado, com o romance $A$ Voz do Oeste (1934); e) artigos publicados no âmbito de revistas que circulavam entre a intelectualidade próxima ao Estado Novo; f) relatos de viagens escritos na década de 1930 por aventureiros e jornalistas, tais como Roncador, de Willy Aureli ([1939]1962).

Neste artigo, entretanto, limito-me a tomar três obras exemplares dessa vasta literatura como forma de apresentar as dimensões do repertório cultural associado ao Brasil. Para tanto, analiso brevemente os livros Viagem ao Araguaia, de Couto de Magalhães (1957), Problemas do 
Brasil, de Everardo Backheuser (1933), e Oeste, de Nelson Werneck Sodré (Sodré, 1941). O primeiro é o registro clássico da região, produzido por um jovem governador provincial no Segundo Reinado que combinava a excitação da viagem "exótica" com um olhar já animado pela modernização capitalista. Essa obra foi reeditada no período republicano, sendo exaustivamente citada por funcionários estatais no governo Vargas. Já a obra de Backheuser é uma dos mais significativos livros geográficos que buscam pensar o Brasil por intermédio de uma linguagem associada à nascente geopolítica europeia. O terceiro é exemplar da literatura produzida no âmbito da política cultural do Estado Novo, e evidencia a consolidação de imagens tidas como típicas da região que seria alvo da Marcha para Oeste. Vale ressaltar que a pesquisa incorpora numerosas obras, mas por razões de espaço seria impossível fazer uma exaustiva análise do material levantado.

José Vieira Couto de Magalhães (1837-1898) fez Direito no Largo de São Francisco, em São Paulo, e logo percorreu, com destaque, o percurso que combinava letras e política no Segundo Reinado. Sob proteção do Visconde de Ouro Preto, foi nomeado governador da província de Goiás com apenas 24 anos, em 1862. Em 1864 se deslocava para o Pará, e dois anos depois, ia para o Mato Grosso por conta da Guerra do Paraguai. Após sua publicação original, Viagem ao Araguaya ganhou outra edição em 1889, ainda que mal organizada. Depois, seria incorporada à coleção Brasiliana e reeditada pela Companhia Nacional em 1934, ganhando estatuto de clássico. Note-se, aliás, que, no âmbito da Brasiliana, são reeditados na segunda metade dos anos 1930 os livros de viagens de Saint-Hilaire, além de se lançar a primeira edição de Viagem pelo Amazonas e Rio Negro, de Alfred Russel Wallace, configurando uma espécie de boom da literatura de viajantes. Como se verá na próxima seção, mesmo relatórios militares produzidos no âmbito das atividades da FBC incorporariam a linguagem dessa literatura.

No livro sobre o Araguaia, Couto de Magalhães narra seu trânsito pela região que iria presidir. A primeira parte da obra é, na verdade, um prefácio onde o autor expõe suas ideias gerais sobre o aproveitamento econômico do espaço. As convicções liberais do jovem governador fazem-no criticar a apatia moral do Estado, fenômeno intensificado pelo predomínio político de uma velha capital colonial, esvaziada de sentido econômico e organizada em torno do trabalho burocrático. Defende, portanto, a mudança de capital com o intuito de incrementar a infraestrutura do espaço, explorando o potencial do transporte fluvial e 
organizando a vida política a partir do incremento das atividades mercantis. Percebe-se, portanto, como Couto de Magalhães localiza no interesse a chave para a sustentação de uma ordem social mais dinâmica e menos letárgica.

Ao mesmo tempo, o relato é permeado de impressões a respeito da grandiosidade da natureza da região. O narrador dessa viagem mostra-se impregnado dos motivos típicos da sensibilidade romântica, extasiando-se diante dos grandes espaços despovoados e sentindo-se aterrado pela dimensão sublime da vegetação luxuriante. Uma passagem típica desse modelo de expressividade encontra-se na sua descrição de um jantar à moda indígena, que termina da seguinte maneira:

Com essa simples cozinha, por mesa e toalha o leito frio da areia, tivemos um magnífico jantar, tanto mais agradável, quanto o sol, que pendia já para o ocidente, dava ao céu achatado um colorido de verde claro morrendo em roxo, que filtrava pelo espírito uma sensação agradável e melancólica, de indefinível saudade. (Couto de Magalhães, 1957:80)

Há inúmeros trechos como este ao longo da obra, nos quais o narrador pontua sua solidão de aventureiro perdido nos confins do Brasil Central. Porém, essas passagens combinam-se a outras em que predomina o enfoque racional do liberalismo econômico, que enquadra o território sob a ótica do interesse. Por exemplo:

A serra do Acaba-saco vai sucessivamente abaixando-se, até que de todo se confunde com as planícies. Parei extasiado nesse lugar e, enquanto a vista me representava essas planícies sem fim, sucedendo-se umas às outras, como as ondas do oceano, até que de todo se iam perder nos espaços azulados do céu, meu espírito sentia-se abatido por uma espécie de saudade, que eu não sabia dizer de que, e a imaginação me representava completamente desertas essas férteis e infinitas campinas. [...] Quando chegará, meu Deus, disse eu a mim mesmo, quando chegará o dia em que se verão espalhar florescentes cidades nas margens destes rios! (id.:74)

Finalmente, note-se a constante percepção de uma atmosfera de decadência, traduzida pelas referências feitas pelo autor às ruínas de presídios, habitações e prédios públicos, encontradas ao longo de seu trajeto pelo Araguaia. Estamos distante, portanto, da ideia do Brasil Central como simples deserto, geografia despovoada de referências históricas. Couto de Magalhães apresenta um território em constante fazi- 
mento, como se as iniciativas do Estado sempre fossem desfeitas pela força da imensidão espacial. Como exemplo, temos a passagem pela localidade de Santa Rita, junto ao rio do Peixe, sobre a qual o governador anota: "O extinto porto de Santa Rita é um rochedo sobre o qual bateu perpendicularmente as águas do rio, para se escoarem depois para o lado do norte; é hoje uma velha tapera, e do grande armazém que aí houve, dos botes que flutuavam sobre as águas verdecentes do rio, existe apenas a memória" (id.:79).

Para Francisco Foot Hardman (Hardman, 1992; 1996), o tema das ruínas atravessa parte significativa do pensamento brasileiro sobre a modernidade, traduzindo um sentimento melancólico diante dos efeitos destruidores do capitalismo em territórios movediços como os dos interiores brasileiros. Isto é, não seria peça excêntrica o relato de Couto de Magalhães, expressando os dilemas da própria subjetividade do autor, misto de administrador, empresário capitalista e escritor romântico (Machado, 1998).

De modo geral, pode-se dizer que a obra de Couto de Magalhães contribuiu para configurar um modo de falar sobre o Oeste brasileiro que combinava diversas matrizes. Ao mesmo tempo em que lamenta a improdutividade e a decadência do espaço, exalta sua qualidade encantatória e a promessa de futuro nele contida. O livro também ajudou a ressaltar o tema fluvial ao exaltar a importância do Araguaia como via de transporte. A partir de então, pensar, falar e agir sobre a região demandaria mobilizar o rio como objeto por excelência de qualquer descrição ou avaliação do território. Finalmente, destaque-se a linguagem da aventura, que marcaria decididamente todos os relatos de viagem posteriores à região (Maia, 2007), disseminando-se, inclusive, por textos burocráticos ou militares, nos quais não se esperaria encontrar tais artifícios. Nos anos de 1930, outros relatos surgiram, agora produzidos sob a égide da recuperação paulista do bandeirantismo. Refiro-me a livros como Roncador, de Willy Aureli (1939), e Garimpos de Mato Grosso (1936) e Nos Sertões do Araguaia: Narrativas sobre a Expedição às Glebas Bárbaras do Brasil Central (1935), estes escritos por Hermano Ribeiro. Todos esses escritos são narrativas de expedições chefiadas por dublês de jornalistas-exploradores, que organizam caravanas de jovens aventureiros paulistas em direção ao chamado Brasil Central. Partilham, em larga medida, a estética da aventura analisada acima. Trata-se, agora, de localizar os pressupostos cognitivos de outro modo de representação do Oeste brasileiro, contido na imaginação geopolítica nacional. 
Figura intelectual de destaque na Primeira República, Everardo Backheuser foi membro da Sociedade de Geografia do Rio de Janeiro, fundador do Curso Livre de Geografia Superior, professor da Politécnica (sua tese de cátedra foi apresentada em 1918) e membro fundador da Associação Brasileira de Educação. Essa intensa circulação entre postos de prestígio no mundo científico do período lhe granjeou não apenas prestígio, mas receptividade para seus escritos, que de certa forma sintetizam as grandes macrovisões sobre o território brasileiro. Colega de outros "renovadores da geografia", como Delgado de Carvalho e Raja Gabaglia, Backheuser publicou em 1933 livro fundador da geopolítica nacional, intitulado Problemas do Brasil: Estrutura Geopolítica (o Espaço). Nessa obra está presente sua leitura de Alberto Torres e suas incursões no pensamento geopolítico alemão e sueco, representados por Friedrich Ratzel e Rudolf Kjéllen, respectivamente.

O livro parte da discussão sobre a dimensão grandiosa do espaço brasileiro, tido como tema que produz vantagens e desvantagens, analisadas no livro. Ao fazer isso, Backheuser inscreve a territorialidade brasileira numa chave global mais ampla, que divide os países centrais, que cresceram naturalmente a partir de suas cidades, dos países coloniais, que foram construídos "a jato", por atos de vontade. Para explicar essa diferença, uma metáfora química baseada nas características do corpo amorfo e do agregado cristalino é mobilizada. Segundo o autor, a França, por exemplo, constitui-se como um agregado que atrai de forma constante, num arranjo federativo, ao contrário dos países coloniais, que mudam de estado muito rapidamente, ganhando uma territorialidade dura.

Essa metáfora permite a Backheuser traçar as características da geopolítica brasileira: colonizado de forma espontânea e irregular, o Brasil careceria de um ordenamento equilibrado, conduzido pelo Estado, que não levasse em conta o peso do regionalismo, tido como uma tradição fora do lugar num país constituído pela condição colonial.

Ao tomar os temas da divisão regional e da localização da futura capital como seus eixos de discussão, Backheuser dá corpo teórico aos assuntos que ocupavam a agenda territorial de políticos e burocratas ao longo da Primeira República. Seu argumento inscreve o vasto território brasileiro num conjunto que abriga países de origem colonial cujo crescimento não se deu de forma lenta e espontânea, a partir de burgos que viravam cidades. Isso teria produzido desequilíbrios demográfi- 
cos e demandaria uma estratégia racional de ordenamento espacial. Assim, enquanto na porção "Eurasiana" os países teriam sido compostos por um crescimento progressivo a partir do centro, nas ex-colônias o território teria se constituído das periferias para o centro, num processo desordenado. Isso justificaria o ativismo estatal e a desconsideração da tradição como elemento ordenador de fronteiras internas.

Raciocínio semelhante é empregado para defender a mudança de capital, outro tema clássico na imaginação espacial brasileira. Segundo Backheuser, sociedades de passado colonial como a brasileira não teriam capitais que representariam o acúmulo de uma lenta tradição orgânica. Assim, estariam acostumadas ao artificialismo do ordenamento político, que seguiria critérios racionais.

Esse enquadramento, que situa o Brasil como um país pós-colonial produzido de forma "não natural", ecoa argumentos clássicos de Alberto Torres a respeito da necessária dimensão de artifício que presidira a atividade política no país. Isto é, num país onde a tradição não operaria como eixo fundador da vida nacional, seria possível apelar para uma razão central ordenadora como ferramenta de operação espacial.

Essa formulação encontraria acolhimento nas elites burocráticas e políticas que ascendem ao poder em 1930 e ocupam postos-chave nas agências estado-novistas. Mário Augusto Teixeira de Freitas (1890-1956), um dos principais formuladores do IBGE, era leitor assíduo de Torres, além de acompanhar com atenção os debates sobre divisão regional, nos quais Backheuser era autoridade. Ou seja, o desenho estatal do mundo possível do Brasil Central teria como pressuposto cognitivo a assunção da perspectiva que via esse espaço pelo prisma da nossa condição periférica e nova.

Vale dizer que esta discussão geopolítica sobre os espaços "vazios" do Brasil tinha enorme repercussão entre setores da elite militar e estatal nos anos 1930 e 1940, seja em revistas geográficas editadas no âmbito do Estado Novo (Maia, 2009), seja a partir da reedição de obras como Projeção Continental do Brasil, escrita por Mário Travassos originalmente em 1931. Nesse contexto se inscreve Oeste, livro de Nelson Werneck Sodré publicado em 1941, cujo subtítulo era "ensaio sobre a grande propriedade pastoril". Trata-se de trabalho exemplar para o tema analisado neste artigo, tanto pelas características do autor - então um militar, tendo se formado em 1934 - como pelo modo como o texto consoli- 
As Ideias que Fazem o Estado Andar: Imaginação Espacial, Pensamento Brasileiro...

da diversas imagens e informações relacionadas aos espaços do Brasil Central. Sua bibliografia contém citações de geógrafos europeus clássicos (Ratzel, Brunhel e La Blanche), etnógrafos (Baldus), clássicos de viagens nacionais (Rondon e Roquette Pinto, este fartamente citado com seu Rondônia), historiadores e economistas (Roberto Simonsen) e geopolíticos (Lima Figueiredo e Travassos), entre outros. Nesse sentido, Oeste consubstancia o repertório amplamente disseminado ao longo da Primeira República sobre o Oeste e o Brasil Central, termos por vezes intercambiáveis.

E qual o retrato delineado pela obra? Na seção "Panorama" já se pode ter uma boa ideia sobre a grande angular de Werneck Sodré. Segundo ele, o Oeste seria marcado pelo latifúndio, pela errância de suas gentes, pela ação dilatadora do território e pela pobreza generalizada. Ao mesmo tempo, enfatiza o forte veio autonomista da região, que atribui à facilidade de movimento naqueles vastos espaços. Note-se, aliás, que essa visão é fortemente aparentada daquela apresentada por Oliveira Vianna em Populações Meridionais do Brasil, obra seminal para o pensamento brasileiro da década de 1920.

Qual o espaço exato de sua análise? Segundo o próprio autor, o recorte inicia-se em Sete Quedas rumo ao Oeste, parte da serra do Maracaju, segue pela linha divisória entre Paraná e Paraguai, e "Para leste, até a caixa do Paraná, desenvolvem-se os intermináveis chapadões onde o pastoreio encontra uma enorme extensão. Para oeste, logo após a queda brusca das escarpas da Bodoquena, amplia-se o panoramente infinito do pantanal" (Sodré, 1941:14).

Ao descrever os ciclos econômicos e demográficos dessa região, Sodré enfatiza a força dos rios e das águas, que constituem na sua narrativa verdadeira força condutora dos homens e dos grandes clãs familiares. Assim, a visão de um "desertão" espacial, amplo e dilatado, convive com a percepção de que os homens se esparramam ao sabor dos cursos fluviais, configurando um território pobre em que os habitantes não encontram dificuldades para adentrar. Assim, ao contrário de outras regiões, não haveria luta entre homem e meio e, consequentemente, não surgiriam laços de solidariedade e integração social. Tudo se passa como se a água e o deserto se combinassem para produzir o Oeste das distâncias e do "vazio". No registro do autor,

Os clãs primitivos, os Barbosa, os Pereira, os Garcia, os Lopes, são os mais inquietos. Marcados pelo destino inexorável, andam permanente- 
mente na peregrinação que só declina com a morte" [...]. Não se criou, por isso mesmo, jamais, uma tradição, uma força íntima e obscura que ligasse esses campeadores solitários e tenazes a um pedaço de chão, nem mesmo ao chão em que haviam sepultado os pais, os avós, os filhos, os irmãos. Nada os prendia. Insubmissos a qualquer laço permanente, não se sujeitavam à dependência, ao entrecruzamento de interesses, às ações reflexas que fazem o amor do solo que se cultivou e que sustentava os seres que o amanham. (id.:87)

E quais são os personagens dessa aventura? São as famílias pastoris, os grandes clãs de criadores donos de latifúndios extensos. São os seus vaqueiros - também nômades - e os garimpeiros - sempre em confronto com o poder central do Estado. Todos compartilham as mesmas características comuns ao regime pastoril nesses vastos espaços: nomadismo e ausência de qualquer apreço por propriedade, solo e cultivo. No registro de Sodré, nota-se que há um permanente inventário de ausências, como se a esses homens faltassem as virtudes características da economia moral burguesa.

Sodré recorre largamente à matriz discursiva euclidiana, que transforma a geologia num ator dramático, capaz de produzir personagens expressivos e formas de vida rudes e distantes do repertório tido como "civilizado". Vejamos essa passagem na seção "Aspectos geográficos":

O grande sistema brasileiro prolonga-se, em seus limites extremos, com as serras de nordeste de Mato Grosso e as alturas que cruzam o Estado de sudeste para noroeste, continuando na serra dos Parecis de que a de Ricardo Franco é uma das partes [...]. Tais indicações orográficas divorciam-se, fundamentalmente nas suas origens, quando se afiguram antigas, perfeitamente delineadas, obras acabadas e polidas, na parte leste, com a caixa do Paraná já definitivamente assente, tanto quanto podem ser definitivas as transformações geológicas. De outro lado, na parte de oeste, tudo é improvisação, movimento, descontinuidade. Terra na infância, ressentindo-se de bruscas mutações ainda recentes, ela se abaixa para a planície do Paraguai, rio caprichoso que não encontrou o seu leito, que muda constantemente, que invade terras, dobra-se, cheio de curvas, lambendo as margens, polindo as beiras, destruindo e construindo, numa obra que não tem fim e que durará tanto quanto se possa prever. (id: 140)

Como se percebe, a sugestão de um Oeste monótono e esparramado convive com a descrição geológica de uma terra instável, em formação, 
ainda não consolidada. Fecha-se, assim, a representação de um espaço que não tem limites definidos ou precisos, assemelhando-se a outro Brasil, ou melhor, ao Outro do Brasil. Terra decadente e instável, esse Outro é também promessa possível de integração nacional e projeção do destino brasileiro. Afinal, Sodré inscreve-se no debate geopolítico de Backheuser, defendendo a necessidade do Brasil se projetar para o eixo norte, já que os rios da bacia do Paraguai conduziriam à região platina, área de influência argentina e uruguaia. Sodré sustenta, então, as imensas possibilidades abertas pela bacia amazônica como eixo capaz de integrar o Brasil e dinamizar seu mercado interno, além de integrá-lo de forma mais eficaz ao continente.

Os retratos de Backheuser e Sodré são marcos da imaginação espacial brasileira sobre o Oeste e o Brasil Central. Ao adotarem um tom geopolítico, permitem que compreendamos mais adequadamente a cognição estatal dessas regiões, vistas sob prisma econômico-político. Já o relato de Couto de Magalhães consagrou uma forma de descrever e "sentir" o Oeste, produzindo uma combinação entre empreendedorismo e sensibilidade poética que será familiar aos homens que manejarão as redes do Estado no longo século XX brasileiro. Ao mesmo tempo, os personagens e os objetos que serão instituídos como típicos desse vasto e ambíguo universo ganham concretude e definição nesses registros, que dialogam fortemente com obras clássicas "maiores" e "menores" no pensamento social brasileiro.

\section{AS PRÁTICAS ESTATAIS DA FBC E OS MUNDOS DO BRASIL CENTRAL}

Nesta seção, analiso documentos primários coletados na pesquisa, tais como relatórios internos e publicações contendo entrevistas e artigos. O objetivo é evidenciar os modos de cognição característicos da atividade estatal da Fundação, apontando o nexo de sentido entre essas práticas comunicativas e o repertório cultural analisado na seção anterior. Para este artigo, separei três temas específicos, que são facilmente detectáveis nas fontes analisadas: a conceituação frouxa do espaço de atuação da Fundação Brasil Central e a delimitação dos objetos e personagens desse universo; a persistência de um olhar geopolítico sobre esses territórios, calcado na lógica da expansão da civilização; e o uso de uma linguagem próxima do registro bandeirantista da "aventura" para dar conta da expansão da autoridade estatal. Creio que esses temas são exemplares para evidenciar a articulação entre ideias e práticas que está sendo sugerida neste artigo. 


\section{Do Espaço Indefinido}

Vejamos inicialmente a própria definição do espaço de atuação da Fundação. Uma boa fonte para isso é um relatório em inglês intitulado "The Central Brazil Foundation: What It Is, What It Does, What It Plans", disponível no arquivo de Artur Hehl Neiva, secretário-geral da FBC durante parte da gestão João Alberto. Devido aos constantes contatos com autoridades norte-americanas e empresários daquele país originados durante o esforço de guerra, não é de se estranhar que os funcionários procurassem explicitar internacionalmente os propósitos da Fundação com o objetivo de angariar recursos e apoio. O documento é exemplar também porque ilustra a própria indefinição sobre qual seria o espaço do Brasil Central: "O domínio da Fundação não tem área definida, a Lei apenas estabelece que suas atividades devem ser executadas no centro e no oeste do Brasil. Essa área possui mais de 5 milhões de quilômetros quadrados" (CPDOC, AHN; tradução minha) ${ }^{5}$.

Esse dado pode ser corroborado por um detalhe significativo presente na revista "Fundação Brasil Central", encarte do periódico "O Observador Econômico e Financeiro", que era uma publicação do empresário Valentim Bouças ${ }^{6}$. Esta separata saía sempre com a mesma capa: um mapa do Brasil em branco, com a região central demarcada por desenhos de animais e plantas "típicas", tudo esquadrinhado por linhas que parecem indicar tanto as fronteiras da área, quanto os caminhos da Expedição Roncador-Xingu. Na contracapa da separata no 5, pode-se ler a seguinte explicação:

A capa deste trabalho, com o mapa do Brasil tendo em "grise" a zona que se pode considerar como o BRASILCENTRAL, é mais uma alegoria do artista que a concebeu do que verdadeiramente um delineamento correto dessa zona, que não comporta delimitação precisa. A linha cheia é o caminho de penetração partindo do Rio e São Paulo, representado pelas estradas de ferro Central e Mogiana até Uberlândia, no Triângulo Mineiro, e estrada de rodagem até Aragarças e, em construção, até a Base do Rio das Mortes. Daí continua, constituindo a marcha próxima da Expedição Roncador-Xingu, em direção aos Rios Xingu e Tapajós, no Estado do Pará, e Canumã, no Estado do Amazonas (CPDOC, JA) ${ }^{7}$.

Como se percebe nos dois documentos, Brasil Central não seria propriamente uma região bem delimitada, mas todo o espaço interior que pudesse ser percorrido pelos agentes da Fundação. Essa forma de cognição do território encontra ressonância no próprio repertório cultural 
anteriormente analisado. O Oeste retratado por Nelson Werneck Sodré estendia-se de forma fluida, delimitado mais pelos caminhos fluviais que modelavam aquela geografia misteriosa do que por fronteiras claramente discerníveis. Como procurei mostrar, essa cartografia tinha sido originalmente fixada por Couto de Magalhães em seu livro de viagens no Araguaia, tido como objeto central para definição da região.

E quais os objetos, os personagens e as qualidades desse espaço de ação estatal? Os documentos permitem atestar a força das imagens cristalizadas no repertório cultural republicano, que delineavam um território marcado pela pobreza, pelo nomadismo das gentes e pela ausência de racionalização econômica. Além disso, o Brasil Central era caracterizado tanto como um espaço de ruínas e isolamento, quanto como o terreno da redenção brasileira, lugar de projeção utópica do país.

Veja-se, por exemplo, a longa entrevista de João Alberto ao Jornal do Brasil, transcrita na publicação em separata no3, cujo título é: “Desbravando o Planalto Central para Além da Serra do Roncador". Nela, o então presidente da FBC afirma: "Não mais a curiosidade ou o lucro fácil impelem os homens a essas paragens imprevistas, mas o interesse da própria existência, o propósito do homem de se fixar ele mesmo ao solo, de explorar a terra, viver ela, plantar, colher e enriquecer por suas próprias mãos" (AN, PAR) ${ }^{8}$.

Nessa passagem, João Alberto reafirma a dicotomia entre uma vivência pouco produtiva e aleatória, que seria típica do modo de vida na região até aquele momento, e a promessa de uma experiência de colonização baseada na propriedade fixa e no trabalho. São constantes em documentos da FBC as referências a essa linguagem que vê o trabalho regular como um antídoto à própria fluidez do espaço e de sua gente, repisando um tema consolidado na literatura geográfica sobre a área. O garimpo e o garimpeiro são outros dois objetos típicos dessa linguagem, como evidencia o restante da entrevista de João Alberto:

Retomando, porém, o fio de nossa conversa sobre o garimpeiro, devo dizer que ele é essencialmente nômade. Abandona a terra de origem, a casa de morada e até a própria família, quando não carrega tudo, mulher e filhos para o que o ajudem na garimpagem, e emigra, na ânsia de fazer fortuna. Todos trazem na imaginação o sonho de encontrar, um dia, uma pedra grande, um diamante de muitos quilates, que lhes dê 
fortuna e independência. E passam a vida correndo atrás dessa fantasia. A pedra grande é como o pássaro azul, que nunca aparece. (ibid.)

Assim, pode-se atestar a cristalização de imagens associadas à decadência, à degradação e às ruínas, temas que já surgiam na prosa de Couto de Magalhães e de outros viajantes, como elementos centrais para narrar os territórios cortados pelo Araguaia. Espaço movente, marcado pelo nomadismo e pela instabilidade, o Brasil Central só conseguiria ser constituído de forma disciplinada pela ação estatal.

\section{Da Linguagem Geopolítica}

Como foi demonstrado na terceira seção, a geopolítica constituiu outro modo consistente de falar sobre o Brasil Central. Esse olhar, traduzido de forma exemplar na obra de Backheuser, mas disponível em outros trabalhos lançados no período, via os espaços internos do país como fronteiras a serem desbravadas e organizadas pelo Estado central, configurando uma ação demiúrgica que se aproxima muito de uma visão colonial sobre o território. Nas fontes pesquisadas, é evidente a incorporação dessa linguagem por parte dos funcionários da FBC.

Um primeiro exemplo está na documentação referente às conversas entre Artur Hehl Neiva, então secretário-geral da Coordenação de Mobilização Econômica, e João Alberto, provavelmente no ano de 1943. Essa conversa discutia o anteprojeto da FBC, que estava sendo apreciada por assessores jurídicos de outros órgãos. Numa carta, Neiva afirma:

Primeiramente, devo ressaltar a excepcional dificuldade do trabalho, pois não existe, em nossa história, paralelo em que se pudesse basear para o fim de fazer obra satisfatória. Isto se deve, excepcionalmente, a situação sui generis do problema, que só foi resolvido com toda sua plenitude em outros países, colonizadores, como a Holanda do século XVI e XVII, com as suas Companhias das Índias Orientais e Ocidentais, as Royal Chartered Companies inglesas do tempo dos Tudor e dos Stuarts, entre elas a Hudson Bay Company, e finalmente as grandes companhias colonizadoras francesas do século XVIII, das quais pode ser tomada como paradigma a da Lousiana. Os fins dessas Companhias eram os mesmos a que se propõe a Fundação. $(\mathrm{ANB}, \mathrm{FBC})^{9}$

E, de fato, essa extrema ambição centralizadora e colonial assustou até a elite burocrática estado-novista, que recomendou alterações que pre- 
servassem prerrogativas por parte dos estados. Mesmo assim, essa linguagem ainda é facilmente percebida em documentos produzidos já durante a operação da FBC. Vejamos como um segundo exemplo um extenso relatório não assinado, de quase 80 páginas, produzido provavelmente no ano de 1944 (pois faz referências a penas a atividades realizadas em 1943 e 1944).

Outros países, não dispondo de novas possibilidades, têm se empenhado num programa análogo, muitas vezes empregando a violência para criar colônias que lhes completem a economia, em terras distantes e regiões insalubres. Nós, ao menos, temos a felicidade de poder resolver esse problema dentro do nosso próprio território. (CPDOC, JA $)^{10}$

Esse colonialismo interno associava-se a uma percepção do espaço interior como um terreno amorfo - conceito caro ao pensamento de Backheuser e à literatura geopolítica nativa em geral -, povoado de forma completamente espontânea e irregular, sem o concurso de uma lógica reguladora estatal. Ainda no relatório anônimo citado acima, pode-se ler:

O povoamento do Brasil deu-se num sentido desordenado. A mineração, que foi a razão fundamental da ocupação do interior, criou centros populosos em regiões desaconselháveis, pelas más condições de salubridade, pela dificuldade de transportes e pela deficiência de produção. Esgotada a terra do ouro ou pedras preciosas, ficaram os lugarejos mal construídos se arrastando numa luta desigual pela existência e sugando, para se manterem, o imposto do município inteiro, de que eles se constituíram em sedes. A política local, nos velhos moldes, se encarregou de oficializar muitos destes erros, desviando as linhas de comunicação de seu traçado normal para atravessar essas cidades. (ibid.)

Não é difícil imaginar os problemas produzidos por uma lógica de expansão do Estado calcada nessa linguagem. E, de fato, a documentação analisada revela inúmeros embates relativos a disputas em torno de terras e concessões, geralmente "negociadas" com os governos estaduais ainda num contexto de forte centralização. Mas os problemas envolviam a própria prática cotidiana desse Estado em marcha. Tome-se como terceiro exemplo o dossiê que relata os conflitos entre os moradores de Tucuruí (PA) e o engenheiro Raul Lambert, ex-diretor da Estrada de Ferro Tocantins, então dirigida pela FBC (embora financiada pelo Ministério da Viação) (ANB, FBC) ${ }^{11}$. 
Nesse dossiê, há um ofício de 24 de maio de 1946 em que o novo diretor, A. Castro Jobim, relata ao Setor Norte da Fundação os inúmeros problemas produzidos pelas atitudes autoritárias de Lambert, que fazia uma política de preços controlada, dirigia de forma despótica os trabalhadores e regulava até a exploração de um castanhal nas proximidades que estaria fora da área da companhia que geria. Interessante notar como Lambert, em sua defesa, assume a necessidade de suas atitudes, alegando a precedência dos interesses nacionais. Segundo ele:

Do próprio relatório consta o descalabro da administração, a desordem implantada em todos os setores, a ponto de não existirem preços únicos na região, mas um preço para a Estrada, e outro preço para os outros. Por que motivos os interesses da Nação ficariam postos em plano secundário? [...] Por outro lado, verifica o Sr. Comandante (sic) que a "invasão de atribuições", de que é acusado o peticionário, refere-se apenas a um ato de disciplina que tomou, de higiene, em benefício da própria população. (ibid.)

\section{Da linguagem bandeirante}

Finalmente, como os funcionários narravam sua atividade e como qualificavam a dinâmica de expansão estatal da FBC? Interessante notar que, mesmo em documentos supostamente burocráticos, a linguagem da aventura bandeirante, comum aos relatos de viagem como os de Couto de Magalhães, era empregada de forma recorrente.

A literatura clássica de viajantes era empregada até como fonte autorizada de conhecimento e informação em numerosos relatórios produzidos por militares, que deveriam subsidiar a Expedição Roncador-Xingu e o trabalho da FBC. Num dossiê de 1943 contendo relatórios militares esparsos, há um produzido pelo coronel João Costa Palmeira, encarregado da Coordenação de Mobilização Econômica, que é repleto de referências a Couto de Magalhães e suas políticas para o Araguaia $(\mathrm{ANB}, \mathrm{FBC})^{12}$. Em outro relatório do mesmo dossiê, escrito pelo comandante Brígido Sobrinho, há mesmo uma bibliografia repleta de relatos clássicos de viagem. Além de Couto de Magalhães, são citados Goyaz, de Taunay, Roteiro do Tocantins, de Lysias Rodrigues, Viagens pelo Amazonas e Rio Negro, do já mencionado A. R. Wallace e De Belém a S. João Araguaia, de Ignácio Moura, entre outras referências.

Mas essa aproximação não se limitava à citação de obras clássicas como recurso para instituir os traçados da autoridade estatal sobre o 
território. Os relatórios incorporavam os próprios modos clássicos de narrar a ação humana sobre o espaço. Ou seja, os agentes incluíam a ideia de aventura, estranha ao mundo impessoal do funcionalismo, nas práticas de expansão da FBC. Tome-se como exemplo o relatório da Comissão de Legislação, Programas e Projetos da FBC, que discute o novo rumo da Expedição Roncador-Xingu em 1948 (MI, FBC) ${ }^{13}$. Tendo atingido sua primeira meta, há uma indefinição com relação ao trajeto que se deveria seguir na nova marcha Xingu-Tapajós. Em seu parecer, o relator Cesário de Andrade incorpora novamente a literatura dos viajantes e vaticina que a escolha do roteiro deve se guiar por caminhos "inexplorados" pelos exploradores passados. Nas suas palavras:

Descer qualquer desses formadores do Tapajós, partindo das proximidades de suas cabeceiras, seria repetir as façanhas dos velhos sertanistas, entre eles o sargento mor Souza Azevedo (1746), o forriel Manoel Gomes dos Santos (1805), Antônio de França, Miguel João de Castro (1812), capitão Bento Miranda (1814), Tenente de milicianos Antonio Peixoto de Azevedo (1820) e inúmeros outros que foram a Belém, seguindo principalmente o curso do Arinos, Juruena e Tapajós. (ibid.)

Em outro momento, afirma:

A finalidade prática da Expedição é explorar a região compreendida entre os dois grandes rios nas proximidades da linha divisória interestadual (Mato Grosso-Pará), isto é, a imensa faixa de terra coberta de florestas seculares, onde o homem civilizado ainda não penetrou e cujas possibilidades econômicas precisam ser aproveitadas. (ibid.)

Outro exemplo pode ser encontrado num grande trabalho de cunho historiográfico sem autoria, disponível no arquivo de Paulo de Assis Ribeiro (AN, PAR) ${ }^{14}$. Nesse trabalho, o autor procura inventariar a história do povoamento e da colonização da região do Brasil Central para situar mais adequadamente as ações da FBC. Note-se que essa preocupação se traduz num imenso inventário de "entradas" e "penetrações", com lista de pioneiros e bandeirantes. Esse inventário passa por figuras modernas do Estado brasileiro, como o general Rondon, e é finalizada no próprio João Alberto, "[...] este bandeirante, por índole e por vocação [...]" (ibid.).

Ao traçar essa linhagem e empregar de forma naturalizada categorias como "penetrações", essa peça burocrática atesta a dimensão não apenas ideológica, mas constitutiva do repertório cultural apresentado 
anteriormente. A linguagem do ineditismo e da aventura, cara à literatura dos viajantes e consolidada no registro de Couto de Magalhães, imiscuiu-se na própria prática discursiva dos agentes estatais, moldando o modo como estes viam o processo de expansão da autoridade estatal por regiões tidas como impenetráveis e misteriosas. Note-se que a combinação entre sensibilidade romântica e olhar econômico-burguês era típica do registro dessa literatura, e instituía o próprio modo de conceber o território do Brasil Central.

\section{CONCLUSÃO}

Como se vê, a relação entre repertório cultural e práticas estatais não se dá no campo da simples influência, termo que diz pouco sobre as diversas formas de apropriação de categorias e modos de cognição. Antes de tudo, a imaginação espacial analisada na terceira seção deste texto operava como mecanismo produtor de sentido, permitindo que fosse possível a criação de órgãos e agências dedicadas a este objeto tão ambíguo e fluido - o Brasil Central. Mas o que este estudo de caso pode nos dizer sobre os processos de formação do Estado brasileiro? Qual a fatura desse vasto trabalho social que articulava ideias e práticas?

Como já deve ter ficado claro a esta altura, o Estado não passou incólume por esse processo de territorialização, pois as práticas e as linguagens aqui analisadas deixaram profundas marcas na configuração do poder estatal tal como praticado no Brasil. Assim, pode-se dizer que a Fundação Brasil Central é exemplar típico da dimensão territorialista do Estado brasileiro (Moraes, 2000), que exige outra interpretação para o clássico tema do nation-building. Na tradição da Teoria Social feita nos centros do capitalismo, o controle público sobre um espaço definido é tido como pressuposto da legitimidade da soberania (Weber, 1999; Bendix, 1996). De forma análoga, a relação entre sociedade e Estado é pautada pela internalização do bem comum nos hábitos cívicos dos homens, produzindo um ajuste que é analisado de diversas maneiras na Sociologia Política extraída da experiência dessas sociedades (Tocqueville, 2005; Putnam, 2002). Pressupõe-se, portanto, uma espécie de normalização do espaço e da vida moral. Como argumentou Philip Gorski (1999), a revolução protestante, ao produzir poderoso mecanismo de subjetivação, foi responsável por um vasto processo de disciplina que produziu coesão social e forneceu aos Estados instrumentos para a regulação da vida cotidiana. 
Ora, no caso brasileiro o território escapou a esse processo de ajuste, sendo invariavelmente visto como objeto a ser domado, desafiando, portanto, a imaginação dos agentes públicos. Se, na Teoria Social Clássica, a adequação entre espaço e vida cívica encontrou seu ponto de convergência na cidade como forma geográfica por excelência, a persistência dos espaços não urbanos no nosso processo modernizador produziu efeitos que sobreviveram à própria urbanização. Afinal, a terra e os sertões tornaram-se os principais modos de cognição de uma sociedade que não encontrou uma identidade estável e assentada. Não à toa, intelectuais e burocratas recorreram com frequência a essas imagens para lidar com os dilemas da autoridade estatal no país.

É argumento comum no pensamento social brasileiro - esta forma singular de sociologia política periférica - a percepção do Estado como uma abstração que não se rotiniza na vida civil, e que paira de forma autônoma sobre os homens (Vianna, 1922). Diante desse fato, percebe-se que o territorialismo é uma possível chave analítica para explicar o Estado em marcha, que só compreende o exercício de autoridade como resultado de uma razão geográfica. Na ausência de "hábitos do coração" ou tradições cívicas que fizessem o ajuste entre Estado e nacionalidade, o espaço é constantemente reinventado, como se fosse possível produzir novas narrativas fundacionais sobre o país que lhe dessem estabilidade. Não à toa, parte significativa da literatura contemporânea na área do pensamento brasileiro chama a atenção para essa dimensão inventiva da nossa linguagem espacial (Lima, 1999; Barboza Filho, 2000; Maia, 2008).

Esse fenômeno seria visível tanto em períodos subsequentes à Marcha para o Oeste, caso da fundação de Brasília e dos planos de colonização empreendidos pelo regime de 1964, como em momentos anteriores, em especial nas Expedições Rondon e no trajeto da famosa Comissão Cruls em busca do centro "verdadeiro" do país. Essa dimensão, é claro, comporta numerosas contradições, como ficou evidente neste artigo. O despotismo burocrático vislumbrado no caso de Tucuruí era apenas pequeno exemplo da dimensão autoritária que envolvia o trato estatal com os personagens do mundo agrário brasileiro. Exemplo mais notório e trágico é o dos soldados da borracha, conduzidos para a morte e a degradação física nos seringais do Norte por ocasião dos esforços de guerra coordenados pelo Estado brasileiro no âmbito dos Acordos de Washington (Secreto, 2007). 
Sabe-se também que a linguagem geopolítica que animou a Fundação e o olhar colonial sobre os sertões brasileiros estão longe de serem relíquias estadonovistas, como se pode verificar ainda na recente aliança entre Estado e grande capital para construção de mega projetos de desenvolvimento no Brasil contemporâneo. Entretanto, há nesse aspecto territorialista decidida qualidade imaginativa, também partilhada por outros personagens do mundo brasileiro que não os burocratas.

Como vem mostrando parte significativa da historiografia nativa ( $\mathrm{Fa}-$ ria, 1998; Campos, 2005; Moura, 2005), o território esteve muitas vezes associado à mobilidade do mundo popular e ao constante desejo de escapar de hierarquias e mecanismos tradicionais de mando. Nesse caso, a reinvenção traduzia-se pela ideia de fronteira, que comporta muito dessa dialética autoridade-liberdade que caracteriza o territorialismo brasileiro. Se, por um lado, a fronteira representa o espaço de afirmação brutal das relações capitalistas mediadas por formas tradicionais e violentas de interação social (Martins, 2009), por outro ela implica a possibilidade constante de se refazer o país de novas formas, sem a inércia das formas de dominação. Em cada projeto estatal de expansão territorial dirigida "de cima", pode-se perceber a energia de atores que o ultrapassam, movidos por seus desejos de liberdade (Becker, 1990). Essa possibilidade relaciona-se com um processo de construção nacional que não seguiu o cânone disponível na teoria clássica sobre Estado e sociedade civil, e que ainda não encontrou decidida resolução. Não por acaso, é nos embates em torno do espaço, seja ele rural seja urbano, que se joga a chance de, mais uma vez, reabrir o Brasil e sua potência democrática. Não é outra a tarefa da imaginação brasileira.

(Recebido para publicação em dezembro de 2009) (Versão definitiva em outubro de 2010) 


\section{NOTAS}

1. A Coordenação de Mobilização Econômica era um poderoso órgão de intervenção econômica criado por Vargas em 1942 com o objetivo de regular a produção e distribuição num contexto de guerra. O fato de João Alberto ser o encarregado da mesma é uma forte evidência do prestígio desfrutado pelo ex-interventor de São Paulo junto aos círculos de comando das elites do Estado Novo.

2. A análise sociológica das redes e da estrutura de sentimentos não pode ser apresentada aqui, por motivos de economia de espaço.

3. A "vanguarda" da Expedição era responsável pela abertura de picadas e campos de pouso, que posteriormente serviriam como bases avançadas da Fundação. Na retaguarda ficavam médicos e pessoal administrativo, que geriam as bases já constituídas e faziam as comunicações entre a vanguarda e o Rio de Janeiro. Os aviões eram importantes para abastecimento da vanguarda e transporte de doentes e feridos, e costumavam auxiliar o trabalho de "desbravamento".

4. Em 1892, uma comissão liderada por Luís Cruls, então diretor do Observatório Nacional, partiu para o Planalto Central com o objetivo de delimitar o centro geográfico do país. A iniciativa visava concretizar a transferência de capital, prevista na Constituição de 1891. Em 1896 publicava-se o relatório da comissão, que ensejou debates sobre a região e suas características.

5. CPDOC, Arquivo Arthur Hehl Neiva, AHN 44.021.20 (arquivo pessoal).

6. Valentim Bouças (1891-1963) era um empresário ligado a Vargas, e que esteve presente em diversas iniciativas econômicas promovidas pela burocracia do Estado Novo. Participou de várias missões econômicas ao exterior. De 1937 até sua morte, foi membro do Conselho Técnico de Economia e Finanças.

7. CPDOC, Arquivo João Alberto, 1945.02.00 (arquivo pessoal).

8. Arquivo Nacional do Rio de Janeiro, Arquivo Paulo de Assis Ribeiro, caixa 16, pasta 2 .

9. Arquivo Nacional do Distrito Federal, caixa 41, dossiê "Estatuto. Projeto dos estatutos da FBC elaborado por FONTEC-RJ 1943-1946".

10. CPDOC, Arquivo João Alberto, Arquivo Fundação Brasil Central 1946.01.12.

11. Arquivo Nacional do Distrito Federal, arquivo Fundação Brasil Central, caixa 55, dossiê "Estrada de Ferro Tocantins código - 945.2 1947".

12. Arquivo Nacional do Distrito Federal, arquivo Fundação Brasil Central, caixa 19, dossiê "Transporte fluvial. Relatório sobre a navegação fluvial nos rios Tocantins e Araguaia 1943".

13. Museu do Índio, Arquivo Fundação Brasil Central, Rolo 303, Fotograma 000264.

14. Arquivo Nacional do Rio de Janeiro, Arquivo Paulo de Assis Ribeiro, caixa 15, pasta 2 . 


\section{REFERÊNCIAS BIBLIOGRÁFICAS}

ALBANEZ, Jocimar Lomba. (2003), Sobre o Processo de Ocupação e as Relações de Trabalho na Agropecuária: O Extremo-Sul de Mato Grosso (1940-1970). Dissertação (Mestrado em História), Universidade Federal de Mato Grosso do Sul.

AURELI, Willy. (1962) [1939], Roncador. São Paulo, Leia.

BACKHEUSER, Everardo. (1933), Problemas do Brasil: Estrutura Geopolítica - O "Espaço". Rio de Janeiro, Omnia.

BARBOZA FILHO, Rubem. (2000), Tradição e Artifício: Iberismo e Barroco na Formação Americana. Belo Horizonte/Rio de Janeiro, UFMG Ed./IUPERJ.

BECKER, Berta. (1990), “Estratégia do Estado e Povoamento Espontâneo na Expansão da Fronteira Agrícola em Rondônia: Integração e Conflito", in B. Becker, M. Miranda e L. Machado (orgs.), Fronteira Amazônica: Questões sobre a Gestão do Território. Brasília, Ed. UnB.

BENDIX, Reinhard. (1996), Construção Nacional e Cidadania: Estudos de Nossa Ordem Social em Mudança. São Paulo, Edusp.

BOTELHO, André. (2007), "Sequências de uma Sociologia Política Brasileira". DADOS, vol. 50, no 1, pp. 49-82.

BRANDÃO, Gildo Marçal. (2005), “Linhagens do Pensamento Político Brasileiro". DADOS, vol. 48, no 2, pp. 231-269.

CAMPOS, Maria V. (2005), “Goiás na Década de 1730: Pioneiros, Elites Locais, Motins e Fronteira", in F. M. Bicalho e V. L. Ferlini (orgs.), Modos de Governar: Ideias e Práticas Políticas no Império Português. Séculos XVI-XIX. São Paulo, Alameda.

COMAROFF, John e COMAROFF, Jean. (1992), Etnography and the Historical Imagination. Boulder/Oxford, Westview Press.

COUTO DE MAGALHÃES, José Vieira. (1957) [1863], Viagem ao Araguaya. São Paulo, Companhia Editora Nacional.

DAYREL, Eliane. (1975), Colônia Agrícola Nacional de Goiás. Análise de uma Política de Colonização. Dissertação (Mestrado em História), Instituto de Ciências e Letras, Universidade Federal de Goiás.

DIMAGGIO, Paul. (1997), "Culture and Cognition". Annual Review of Sociology, vol. 23, pp. 263-287.

DUTRA E SILVA, Sandro. (2002), No Oeste, a Terra e o Céu: A Construção Simbólica da Colônia Agrícola Nacional de Goiás. Dissertação (Mestrado em Sociologia), Universidade Federal de Goiás.

ELIAS, Norbert. (1993), O Processo Civilizador. Rio de Janeiro, Jorge Zahar.

ESCOBAR, Arturo. (1995), The Making and Unmaking of the Third World. New Jersey, Princeton University Press.

ESTERCI, Neide. (1977), O Mito da Democracia no País das Bandeiras. Brasília, Ed. UnB.

FARIA, Sheila de C. (1998), A Colônia em Movimento. Fortuna e Família no Cotidiano Colonial. Rio de Janeiro, Nova Fronteira. 
GOFAS, Andreas e HAY, Colin. (2008), “The Ideas Debate in International and European Studies: Towards a Cartography and Critical Assessment". IBEI Working Papers, no 11, pp. 1-42.

GORSKI, Philip S. (1999), “Calvinism and State-Formation in Early Modern Europe”, in G. Steinmetz (org.), State/Culture: State Formation After the Cultural Turn. Ithaca/London, Cornell University Press.

GUIMARÃES, Fábio. (1941), “Divisão Regional do Brasil”. Revista Brasileira de Geografia, vol. 3, no 2, pp. 318-370.

HANSEN, Thomas B. e STEPPUTAT, Finn. (2001), States of Imagination: Ethnographic Explorations of the Postcolonial State. Durham/London, Duke University Press.

HARDMAN, Francisco Foot. (1996), “Brutalidade Antiga: Sobre História e Ruínas em Euclides". Estudos Avançados. vol. 10, no 26, pp. 293-310.

. (1992), "Antigos Modernistas", in A. Novaes (org.), Tempo e História. São Paulo, Companhia das Letras.

HOCHSCHILD, Jennifer. L. (2006), “How Ideas Affect Actions”, in R. E. Goodin e C. Tilly (orgs.), The Oxford Handbook of Contextual Political Analysis. Oxford, Oxford University Press.

JOSEPH, Gilbert M. e NUGENT, David. (2006) [1994], “Popular Culture and State Formation in Revolutionary Mexico", in G. M. Nugent e D. Nugent (orgs.), Everyday Forms of State Formation: Revolution and the Negotiation of Rule in Modern Mexico. Durham, Duke University Press.

LIMA, Nísia Trindade. (1999), Um Sertão Chamado Brasil. Intelectuais e Representação Geográfica da Identidade Nacional. Rio de Janeiro, Revan.

MACHADO, Maria Helena T. P. (1998), “Introdução”. Diário Íntimo. São Paulo, Companhia das Letras.

MAIA, João Marcelo Ehlert. (2009), Os Sentidos do Oeste: Espaço, Imaginação Social e Construção do Estado. Trabalho apresentado no XIV Congresso Brasileiro de Sociologia. Rio de Janeiro, UFRJ, 28-31 de julho.

. (2008), A Terra como Invenção: O Espaço no Pensamento Social Brasileiro. Rio de Janeiro, Jorge Zahar.

. (2007), “Governadores de Ruínas: Os Relatos de Viagem de Couto de Magalhães e Leite Moraes". Estudos Históricos, no 40, pp. 3-23.

MARTINS, José de Souza. (2009), Fronteira: Degradação do Outro nos Confins do Humano. São Paulo, Contexto.

MEIRELES, Silo. (1960), Brasil Central: Notas e Impressões. Rio de Janeiro, Biblioteca do Exército.

MITCHELL, Timothy. (1991), “The Limits of the State: Beyond Statist Approaches and their Critics. American Political Science Review, vol. 85, no 1, pp.77-96.

MORAES, Antonio C. R. de. (2000), Bases da Formação Territorial do Brasil. O Território Colonial Brasileiro no "Longo" Século XVI. São Paulo, Hucitec.

MOURA, Denise A. Soares de. (2005), Sociedade Movediça: Economia, Cultura e Relações Sociais em São Paulo - 1808-1850. São Paulo, Ed. Unesp. 


\section{João Marcelo Ehlert Maia}

OLIVEIRA, Lúcia Lippi. (1999), "Interpretações sobre o Brasil”, in S. Miceli (org.), O que Ler na Ciência Social Brasileira (1970-1995). São Paulo/Brasília, Sumaré/Anpocs/Capes.

OLIVEIRA, Nilda Nazaré P. (2001), A Economia da Borracha na Amazônia sob o Impacto dos Acordos de Washington e da Criação do Banco de Crédito da Borracha (1942-1950). Dissertação (Mestrado em História Econômica), Faculdade de Filosofia, Letras e Ciências Humanas, Universidade de São Paulo, São Paulo.

POCOCK, John A. (1975), The Machiavellian Moment: Florentine Political Thought and the Atlantic Republican Tradition. Princeton, Princeton University Press.

PUTNAM, Robert. (2002), Comunidade e Democracia: A Experiência da Itália Moderna. São Paulo, FGV Editora.

RIBEIRO DA SILVA, Hermano. (1936), Garimpos do Mato Grosso. São Paulo, Saraiva SA. . (1949) [1935], Nos Sertões do Araguaia. Narrativas das Expedições às Glebas Bárbaras do Brasil Central. São Paulo, Saraiva.

RONDON, Frederico. (1934), Pelo Brasil Central. São Paulo, Companhia Nacional.

SALGADO, Plínio. (1934), A Voz do Oeste (romance-poema da época das bandeiras). Rio de Janeiro, José Olympio.

SECRETO, Maria Verônica. (2007), "A Ocupação dos 'Espaços Vazios' no Governo Vargas: Do 'Discurso do Rio Amazonas' à Saga dos Soldados da Borracha”. Estudos Históricos, no 40, pp. 115-135.

SKINNER, Quentin. (1978), The Foundations of Modern Political Thought. Cambridge, Cambridge University Press.

SODRÉ, Nelson Werneck. (1941), Oeste: Ensaio sobre a Grande Propriedade Pastoril. Rio de Janeiro, José Olympio.

SOUZA LIMA, Antônio Carlos de (org.). (2002), Gestar e Gerir: Estudos para uma Antropologia da Administração Pública no Brasil. Rio de Janeiro, Relume-Dumará.

STEINMETZ, George. (1999), State/Culture: State Formation After the Cultural Turn. Itha$\mathrm{ca} /$ London, Cornell University Press.

SWIDLER, Ann. (2003), Talk of Love. How Culture Matters. Chicago, Chicago University Press.

TILLY, Charles. (1996), Coerção, capital e Estados Europeus. 990-1992. São Paulo, Edusp.

TOCQUEVILlE, Alexis de. (2005), A Democracia na América. São Paulo, Martins Fontes.

TRAVASSOS, Mário. (1935), Projeção Continental do Brasil. São Paulo, Companhia Editora Nacional.

VELHO, Otávio. (1976), Capitalismo Autoritário e Campesinato: Um Estudo Comparativo a partir da Fronteira em Movimento. São Paulo, Difel.

VIANNA, Luiz Werneck. (1997), A Revolução Passiva: Iberismo e Americanismo na Formação Brasileira. Rio de Janeiro, Revan.

VIANNA, Oliveira. (1922), Populações Meridionais do Brasil. São Paulo, Companhia Editora Nacional.

VILLAS-BÔAS, Orlando e VILLAS-BÔAS, Cláudio. (1994), A Marcha para o Oeste. São Paulo, Globo.

WEBER, Max. (1999), Economia e Sociedade. Brasília, Ed. UnB. 


\author{
ABSTRACT \\ Ideas that Move the State: Spatial Imagination, Brazilian Thought, and \\ Territory in Central Brazil
}

This article discusses the relationship between state ideas and practices based on a case study of the Fundação Brasil Central (FBC), an agency created by the Estado Novo regime in 1943 and whose activities extended until 1967. The hypothesis is that Brazilian social thought should be analyzed as a cultural repertoire that produces effects on social life and the state. The article thus analyzes material from the FBC archives and travel records, geopolitical treatises, and other text sources published from the First Republic through the initial years of the Vargas Era. The aim is to show how narratives on Central Brazil shaped the language and practice of public administration.

Key words: Brazilian social thought; Fundação Brasil Central; sociology of culture; Estado Novo

\title{
RÉSUMÉ
}

Les Idées qui Font Avancer l'Etat: Imagination Spatiale, Pensée Brésilienne et Territoire du Brésil Central

Cet article discute le rapport entre les idées et pratiques des états à partir d'une étude de cas centrée sur la Fundação Brasil Central (FBC), institution créée par l'Estado Novo en 1943 et dont les activités se sont prolongées jusqu'en 1967. L'hypothèse est qu'on doit analyser la pensée sociale brésilienne comme un répertoire culturel qui produit des effets sur la vie sociale et sur l'Etat. Pour cela, l'article analyse un matériel d'archives de la FBC et des livres de voyage ainsi que des traités de géopolitique et d'autres sources de textes publiés au long de la Première République et dans les premières années de l'Ere Vargas. Le but est de montrer comment des récits sur le Brésil central ont configuré le langage et la pratique bureaucratique.

Mots-clés: pensée sociale brésilienne; Fundação Brasil Central; sociologie de la culture; Estado Novo 